\title{
Inter-estuary variation and intertidal zonation of free-living nematode communities in tropical mangrove systems*
}

\author{
Daniel M. Alongi \\ Australian Institute of Marine Science, P.M.B. No. 3, Townsville M.C., Queensland 4810, Australia
}

\begin{abstract}
Variation in population densities and community structure of free-living marine nematodes within 5 tropical mangrove systems in northeastern Australia were examined. Nematode densities in surface $(0$ to $5 \mathrm{~cm})$ mangrove sediments were generally low $\left(\overline{\mathrm{x}}=150\right.$ ind $\left.10 \mathrm{~cm}^{-2}\right)$ and ranged from 3 to 987 ind $10 \mathrm{~cm}^{-2}$ Highest densities $\left(\bar{x}=1266\right.$ ind $\left.10 \mathrm{~cm}^{-2}\right)$ occurred in winter in a seagrass flat near the Lockhart River estuary. Densities were not significantly different among estuaries, but differed seasonally (summer $>$ winter) and with intertidal position (low $>$ mid $>$ high). Species diversity $\left(\mathrm{H}^{\prime}\right)$ was low to moderate $(\overline{\mathrm{x}}=2.43$; range: 2.02 to 2.91$)$ and number of species per site was low $(\overline{\mathrm{x}}=23$; range: 11 to 53 species). Numerical classification, detrended correspondence analysis and nodal analysis suggested that nematode faunal groups differed in species composition among intertidal zones and estuaries. Of the 205 species identified, only 3 were found in all 5 estuaries: the deposit feeders Terschellingia longicaudata and Anoplostoma viviparum, and the predator Trissonchulus oceanus. Combining all stations, deposit feeders were the dominant trophic group $(\overline{\mathrm{x}}=50 \%)$ with nearly equal relative abundances of epistrate-feeders $(\bar{x}=28 \%)$ and omnivore/predators $(\bar{x}=22 \%)$. Population densities and species diversity of nematodes in these tropical estuaries are low compared to nematode assemblages in other littoral habitats suggesting that nematode communities in tropical Australian mangroves are subjected to greater stress (e.g. soluble tannins, monsoonal rains) than their counterparts in other intertidal habitats.
\end{abstract}

\section{INTRODUCTION}

The ecology of free-living marine nematode communities has been studied in a variety of benthic environments, mostly in temperate and subtropical seas (Heip et al. 1985). In contrast, few studies on marine nematodes have been conducted in tropical habitats, especially in tidal mangrove forests. Previous investigations of tropical nematodes have usually been taxonomic (e.g. Gerlach 1956a, b, 1957, Decreamer \& Coomans $1978 \mathrm{a}$, b) rather than ecological (Krishnamurthy et al. 1984), and have focussed on communities inhabiting coral reefs (Moriarty et al. 1985, Alongi 1986).

A substantial proportion of the world's coastlines in the tropics are occupied by tidal mangrove forests which are believed to support estuarine and coastal

- Contribution No. 381 from the Australian Insitute of Marine Science. food webs (Milward 1982). In Australia, mangroves occupy approximately $11500 \mathrm{~km}^{2}$ of the coastline with more than $95 \%$ of the forests within the tropics (Galloway 1982). Tropical mangrove forests exhibit distinct and complex zonation patterns from the lower to the upper intertidal zone (Macnae 1969). The zonation patterns of mangroves, particularly in Australia, have been generalized by Macnae (1969) as: the seaward fringe or low intertidal zone, dominated by species of Avicennia, Rhizophora and Sonneratia; the zone of Rhizophora forests or mid intertidal zone, which on an areal basis, comprises most of the mangrove forest; and the zone of Ceriops thickets of the high intertidal zone.

These distinct vegetational patterns result in differences in tidal flushing (Wolanski \& Ridd 1986) and sediment stability and transport within the forest, leading to gradients in sediment texture and grain size under the canopy (Alongi 1987a). In the low and mid intertidal zones, mud and fine sand beds develop in association with the pneumatophores and stilt roots of 
Avicennia and Rhizophora trees; in the high intertidal zone, coarser sands usually dominate (Boto \& Wellington 1984, Alongi 1987a).

In subtropical Australian mangroves, Hodda \& Nicholas $(1985,1986 a, b)$ found that nematodes were abundant $\left(10^{5}\right.$ to $\left.10^{6} \mathrm{~m}^{-2}\right)$ and that densities were highest in the low intertidal zone - a pattern similar to nematode communities in subtropical mangroves in North America (Hopper et al. 1973). In tropical mangrove estuaries along the Cape York peninsula of northeastern Australia, Alongi (1987a) found, however, that meiofaunal densities were lower $\left(10^{2}\right.$ to $\left.10^{5} \mathrm{~m}^{-2}\right)$ than in other mangrove habitats and decreased with tidal elevation. Highest numbers occurred in summer in the estuaries north of $18^{\circ} \mathrm{S}$ latitude (Hinchinbrook Island). In mangroves on Hinchinbrook Island, which are not subjected to torrential summer rains, meiofaunal densities were highest in autumn and winter when sediment temperatures were $<30^{\circ} \mathrm{C}$ (Alongi 1987 a). In this paper, inter-estuary variation and intertidal zonation of the free-living marine nematode communities inhabiting these tropical mangrove systems are examined.

\section{DESCRIPTION OF MANGROVE SYSTEMS}

Five mangrove systems were studied along the northeastern coast of Australia: the Morgan/McIvor, Lockhart, Claude and Escape Rivers (Cape York estuaries), and Missionary Bay at Hinchinbrook Island (Fig. 1). These systems encompass a range of geomorphological and latitudinal variations in tropical Australian mangroves.

The Morgan/McIvor, Claude and Escape Rivers have been categorized as riverine systems with fringing mangrove forests (Bunt et al. 1982b) and receive greater amounts of freshwater runoff than the other 2 systems (Bunt et al. 1982a). Missionary Bay at Hinchinbrook Island and the Lockhart River, in contrast, are deltaic systems with a greater marine input and larger areal extent of mangrove forests (Bunt 1982). The Morgan/McIvor, Lockhart, Claude and Escape Rivers have distinct summer wet and winter dry seasons, whereas Hinchinbrook Island lies on a sharp climatic gradient and receives less monsoonal rain than the estuaries to the north (Bunt 1982).

The estuaries were classified using the Euclidean distance measure (Pielou 1984) on the basis of 14 standardized $(\overline{\mathrm{x}} / \mathrm{SD})$ sedimentary characteristics (intertidal temperature, salinity, redox potential, $\mathrm{pH}$, soluble tannins, percent sand, silt and clay, median grain size, sorting coefficient, percent water content, total organic matter, and organic carbon and nitrogen) presented in Alongi $(1987 a, b)$. The classification (Fig. 2) reveals 2

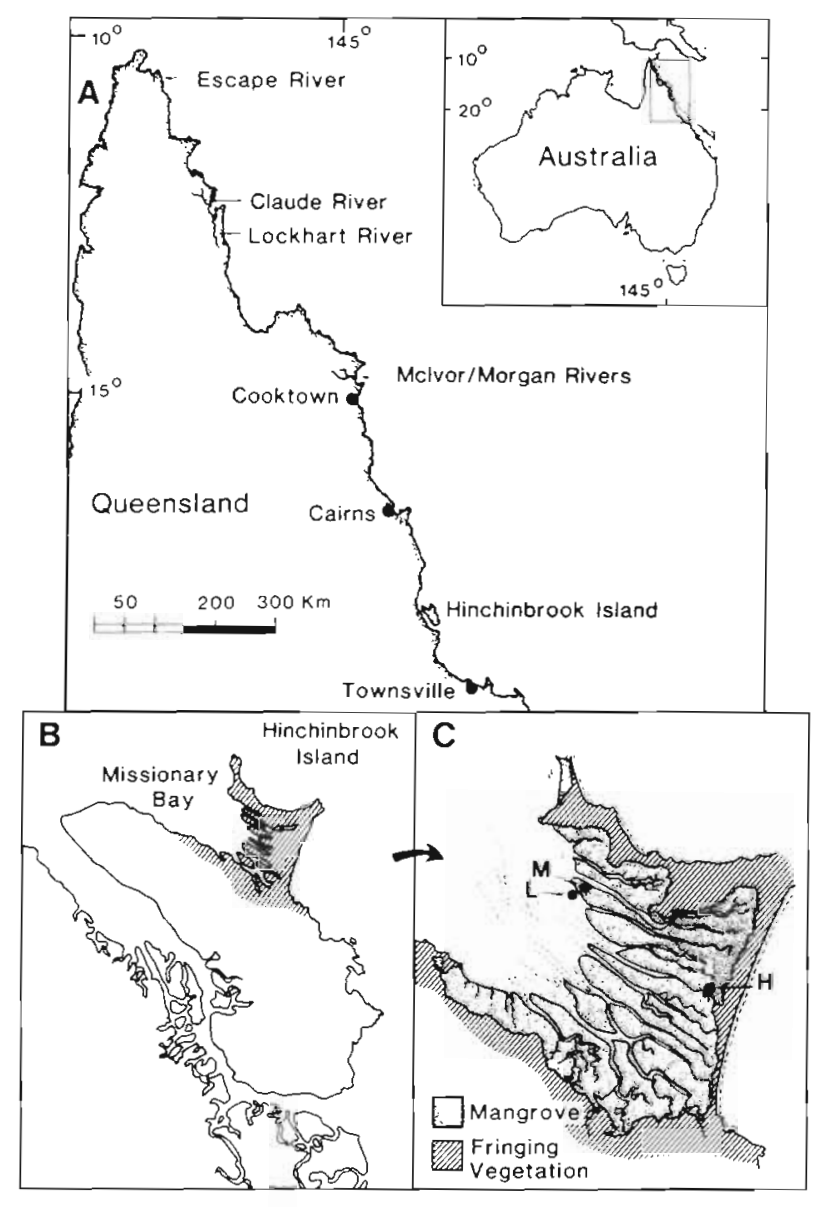

Fig. 1. Northeastern coast of Australia. (A) location of Cape York mangrove estuaries; $(B, C)$ intertidal sites at Missionary Bay, Hinchinbrook Island. L: low intertidal; M: mid intertidal: $\mathrm{H}$ : high intertidal

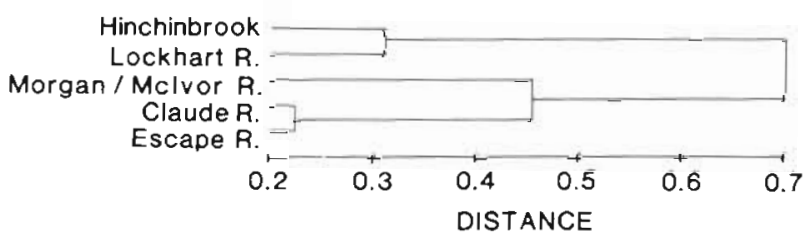

Fig. 2. Normal classification of the 5 mangrove systems based on sediment characteristics presented in Alongi $(1987 a, b, c)$

cluster groups in which the Claude and Escape Rivers are linked with the Morgan/McIvor River, and the Lockhart River is paired with the Hinchinbrook Island system.

Intertidal sediments of the Claude and Escape Rivers, and to a lesser extent, the Morgan/Mclvor River, are characterized by generally lower percentages of organic carbon and nitrogen, and a greater percentage of sand than the Hinchinbrook and Lockhart systems (see summary Table 1). In all estuaries, sediments in the high intertidal zones were coarser, drier and had significantly less organic nitrogen than sediments in 
Table 1. Summary of major environmental factors in the intertidal sediments of the Cape York estuaries and Missionary Bay, Hinchinbrook Island. Each group of winter and summer values represent (from left to right) the low, mid and high intertidal sites. Values for the seagrass bed are in parentheses. Summarized from data included in Alongi $(1987 \mathrm{a}, \mathrm{c})$

\begin{tabular}{|c|c|c|c|c|c|c|c|}
\hline Estuary & $\begin{array}{l}\text { Tempera- } \\
\text { ture }\left({ }^{\circ} \mathrm{C}\right)\end{array}$ & Salinity $(\% \circ)$ & $\%$ Sand & $\%$ Silt-clay & $\begin{array}{l}\text { Median grain } \\
\text { size }(\varnothing)\end{array}$ & $\begin{array}{l}\text { Organic car- } \\
\text { bon }(\% \text { by wt) }\end{array}$ & Sediment type \\
\hline \multicolumn{8}{|c|}{ Morgan/Miclvor } \\
\hline Winter & $21,19,19$ & $16.1,27.6,26.7$ & $40.2,31.6,86.9$ & $59,8,68.4,13.1$ & $7.3,7.8,2.5$ & $1.2,2.4,0.8$ & $\mathrm{~ms}, \mathrm{~ms}, \mathrm{fs}$ \\
\hline Summer & $35,29,33$ & $13.1,22.8,18.5$ & $57.2,59.1,94.8$ & $42.8,40.9,5.2$ & $5.0,5.7,2.2$ & $1.4,2.1,0.8$ & $\mathrm{~ms}, \mathrm{~ms}, \mathrm{fs}$ \\
\hline \multicolumn{8}{|l|}{ Claude } \\
\hline Winter & $26,24,23$ & $19.4,20.1,20.9$ & $46.0,15.7,94.5$ & $54.0,84.3,5.5$ & $5.4,8.4,-1.0$ & $2.8,6.8,1.1$ & $\mathrm{~ms}, \mathrm{~m}, \mathrm{vcs}$ \\
\hline Summer & $29,28,27$ & $4.4,19.4,6.0$ & $86.5,37.6,89.1$ & $13.5,62.4,10.9$ & $0.2,6.4,-0.7$ & $2.0,7.3,1.2$ & $\mathrm{cs}, \mathrm{ms}, \mathrm{vCs}$ \\
\hline \multicolumn{8}{|l|}{ Lockhart } \\
\hline \multirow[t]{2}{*}{ Winter } & $24(31)$ & $29.8(31.7)$ & $0.6(79.8)$ & $99.4(20.2)$ & $9.1(3.4)$ & $8.8(2.4)$ & \\
\hline & 21,33 & $28.7,30.2$ & $50.2,33.9$ & $49.8,66.1$ & $5.9,7.4$ & $8.6,5.0$ & $\mathrm{~m}(\mathrm{vfs}), \mathrm{ms}, \mathrm{ms}$ \\
\hline \multirow[t]{2}{*}{ Summer } & $30,(31)$ & $20.8(27.9)$ & $45.1(75.8)$ & $54.9(24.2)$ & $6.4(3.6)$ & $7.9(2.0)$ & \\
\hline & 29,28 & $19.6,26.7$ & $47.2,76.9$ & $52.8,23.1$ & $5.7,4.0$ & $9.1,3.3$ & $\mathrm{~ms}(\mathrm{vfs}), \mathrm{ms}, \mathrm{vfs}$ \\
\hline \multicolumn{8}{|l|}{ Escape } \\
\hline Winter & $23,22,23$ & $24.8,32.1,32.0$ & $61.5,19.4,93.1$ & $38.5,80.6,6.9$ & $5.1,7.9,2.7$ & $3.9,8.1,2.0$ & $\mathrm{~ms}, \mathrm{~m}$, fs \\
\hline Summer & $28,27,26$ & $17.2,25.1,11.0$ & $76.6,76.5,96.7$ & $23.4,23.5,3.3$ & $3.9,3.9,1.9$ & $2.4,3.8,2.1$ & vfs, vfs, mds \\
\hline \multicolumn{8}{|c|}{ Hinchinbrook } \\
\hline Winter & $15,16,18$ & $33,34,54$ & $0,0,63.3$ & $100,100,36.7$ & $10.2,9.8,4.5$ & $4.2,11.2,4.8$ & $\mathrm{~m}, \mathrm{~m}, \mathrm{~ms}$ \\
\hline Spring & $28,28,28$ & $36,36,45$ & $0,0,76.8$ & $100,100,23.2$ & $10.5,10.3,4.0$ & $4.9,13.4,4.0$ & $\mathrm{~m}, \mathrm{~m}, \mathrm{~ms}$ \\
\hline Summer & $31,27,40$ & $34,35,59$ & $0,0,74.7$ & $100,100,25.3$ & $9.7,9.5,3.8$ & $5.1,12.2,6.9$ & $\mathrm{~m}, \mathrm{~m}, \mathrm{~ms}$ \\
\hline Autumn & $23,27,25$ & $33,35,38$ & $0,0,62.8$ & $100,100,37.2$ & $10.0,9.9,4.5$ & $4.9,10.8,3.7$ & $\mathrm{~m}, \mathrm{~m}, \mathrm{~ms}$ \\
\hline
\end{tabular}

the low and mid intertidal zones. In all of the estuaries, sediments in the mid intertidal zones were significantly more organic-rich (as total organic matter, organic $\mathrm{C}$ and $\mathrm{N}$ ) than the other 2 zones (Alongi 1987a). During this study, prolonged summer rains occurred north of Hinchinbrook Island resulting in increased river discharge and scouring of surface silts and clays and associated organic matter from the intertidal sediments of each estuary.

\section{MATERIALS AND METHODS}

Sampling procedure and laboratory analysis. The low, mid and high intertidal zones corresponding to the mangrove vegetational patterns were sampled for nematodes near ( $\sim 0.5$ to $2 \mathrm{~km}$ inside) the river mouth of each estuary. An additional station was located within a seagrass bed near the mouth of the Lockhart River. The seagrass flat is dominated by 2 species: Halophila ovalis and Halodule sp.

Samples were taken at each site at low tide before noon (0900 to $1200 \mathrm{~h}$ ). The intertidal sites at Missionary Bay, Hinchinbrook Island were sampled in autumn (May 1985), winter (Jul 1985), spring (Oct 1985) and summer (Jan 1986). The Cape York estuaries north of Hinchinbrook Island were sampled during winter dry (Jul 1985) and summer monsoon (Jan 1986) seasons.
Three plastic cores $\left(6.6 \mathrm{~cm}^{2}\right.$ surface area) were taken at each station for meiofauna to a depth of $5 \mathrm{~cm}$ and subdivided initially into 0 to 2 and 2 to $5 \mathrm{~cm}$ portions. Each core was preserved in a $1: 500(\mathrm{v} / \mathrm{v})$ mixture of Rose Bengal $\left(0.5 \mathrm{~g} \mathrm{l}^{-1}\right)$ in buffered seawater formalin $(5 \%)$. Preliminary sampling at Hinchinbrook Island at low and high tide to a depth of $1 \mathrm{~m}$ indicated that $>85$ to $95 \%$ of the nematodes were found within the top $5 \mathrm{~cm}$ in each intertidal zone. In the laboratory, sediments were passed through a set of 2 sieves, the top one with a mesh opening of $500 \mu \mathrm{m}$ and the bottom screen with a mesh size of $45 \mu \mathrm{m}$. Nematodes retained on the $45 \mu \mathrm{m}$ mesh were carefully sorted from debris, enumerated and identified to species level when posible. Nematodes were classified for feeding type (deposit feeder, epigrowth feeder or omnivore/predator) by the scheme of Wieser (1953).

Data analysis. Differences in nematode densities were tested using a nested 3-way (Mixed Model) analysis of variance (Sokal \& Rohlf 1969). In the analyses, seasons were nested within intertidal zones in each estuary with estuaries as the main treatments. A nested 2-way ANOVA was used to test for differences within the Hinchinbrook Island fauna by nesting seasons within intertidal positions. Each ANOVA was followed by a Student-Newman-Keuls (SNK) multiple comparisons test to determine which values were significantly greater or less than others (2-tailed test). Nematode 
densities were log $(x+1)$ transformed when homogeneity of variance was rejected by an $F_{\max }$ test. Species diversity $\left(\mathrm{H}^{\prime}\right)$ was measured by the Shannon-Wiener information function using $\log _{e}$ (Pielou 1975), evenness $\left(\mathrm{J}^{\prime}\right)$ was calculated after Pielou (1975) and species richness (SR) was estimated by the formula of Margalef (1958).

Log $(x+1)$ transformed data were used to classify the sites and the nematode assemblages using the BrayCurtis similarity measure (Bray \& Curtis 1957) with flexible sorting and the cluster intensity coefficient $(\beta)$ set at -0.25 (Clifford \& Stephenson 1975). Species groups in the inverse classification were subjectively determined by accepting $50 \%$ similarity as the discrimination point and by their consistency relative to the original sites $\times$ species data matrix (Boesch 1977 . Alongi 1986). A cross relation between normal (sites) and inverse (species) classifications, termed nodal analysis (Lambert \& Williams 1962), was performed to describe the sites on the basis of their characteristic species and the species on their patterns of occurrence in the estuaries. Comparisons of coincidence are expressed in terms of constancy, the degree to which a species or species group is consistently found in a habitat, and fidelity, the degree to which a species or species group selects or is relegated to a habitat. When a species group occurs in all collections of a station the constancy index will take a value of 1 and of 0 when the species group does not occur in the site collections. The fidelity index is 1 when the constancy of a species group at a station is equivalent to its overall constancy. $>1$ when its constancy in a particular collection group is greater than its overall constancy, and $<1$ when its constancy is less than its overall constancy. Equations for the constancy and fidelity terms are found in Boesch (1977) and Tietjen (1984).

Detrended correspondence analysis (DCA), a modification of reciprocal averaging ordination, was performed using all nematode species identified. The technique has been described in detail by Hill (1979) and Hill \& Gauch (1980).

\section{RESULTS}

\section{Population densities and species diversity}

Nematode densities (Table 2) were not significantly different $(p>0.05)$ among estuaries (including Hinchinbrook Island winter and summer fauna), but differed seasonally and with intertidal position. Differences in intertidal position explained $56.8 \%$ of the variance; seasonality and within site differences accounted for 13.7 and $29.5 \%$ of the variance, respectively. In each estuary, densities decreased significantly $(p<0.01)$ from the low to the high intertidal and were significantly $(\mathrm{p}<0.01)$ greater in summer than in winter (excluding the Lockhart River seagrass fauna

Table 2. Mean ( $\pm 1 \mathrm{SD}$ ) population densities (ind $10 \mathrm{~cm}^{-2}$ ) of nematodes in low, mid and high intertidal regions of the Cape York estuaries and at Missionary Bay, Hinchinbrook Island. Values in parentheses: densities in seagrass bed

\begin{tabular}{|c|c|c|c|}
\hline \multirow[t]{2}{*}{ Estuary } & \multicolumn{3}{|c|}{ Intertidal zone } \\
\hline & Low & Mid & High \\
\hline \multicolumn{4}{|c|}{ Morgan/McIvor } \\
\hline W & $819 \pm 593$ & $138 \pm 49$ & $53 \pm 20$ \\
\hline $\mathrm{S}$ & $987 \pm 449$ & $197 \pm 182$ & $65 \pm 23$ \\
\hline \multicolumn{4}{|l|}{ Claude } \\
\hline W & $108 \pm 33$ & $60 \pm 27$ & $98 \pm 43$ \\
\hline $\mathrm{S}$ & $137 \pm 44$ & $74 \pm 33$ & $116 \pm 30$ \\
\hline \multicolumn{4}{|l|}{ Lockhart } \\
\hline W & $54 \pm 28(1266 \pm 280)$ & $17 \pm 9$ & $3 \pm 2$ \\
\hline$S$ & $147 \pm 98 \quad(313 \pm 171)$ & $54 \pm 18$ & $62 \pm 17$ \\
\hline \multicolumn{4}{|l|}{ Escape } \\
\hline W & $270 \pm 139$ & $68 \pm 38$ & $52 \pm 33$ \\
\hline $\mathrm{S}$ & $372 \pm 233$ & $62 \pm 11$ & $59 \pm 24$ \\
\hline \multicolumn{4}{|c|}{ Hinchinbrook } \\
\hline W & $370 \pm 70$ & $53 \pm 15$ & $41 \pm 0$ \\
\hline $\mathrm{Sp}$ & $77 \pm 29$ & $52 \pm 10$ & $14 \pm 8$ \\
\hline S & $240 \pm 160$ & $46=18$ & $16 \pm 23$ \\
\hline A & $200 \pm 10$ & $170 \pm 50$ & $42 \pm 34$ \\
\hline
\end{tabular}


where the opposite occurred, and the mid intertidal fauna of the Escape River where no seasonality was evident). On Hinchinbrook Island, densities (Table 2) also decreased significantly with tidal height (all seasons except in winter when mid and high intertidal abundances were not significantly different). Within intertidal position, highest densities occurred in autumn in the mid intertidal, and in autumn and winter in the high intertidal. In the low intertidal, highest numbers occurred in winter.

Table 3. Species diversity $\left(\mathrm{H}^{\prime}\right)$ evenness $\left(\mathrm{J}^{\prime}\right)$, species richness (SR) and number of species (NS) per station in the 5 mangrove systems. Values depict summed winter and summer faunas

\begin{tabular}{|c|c|c|c|c|}
\hline Estuary & $\mathrm{H}^{\prime}$ & $J^{\prime}$ & $\mathrm{SR}$ & NS \\
\hline \multicolumn{5}{|c|}{ Morgan/Mclvor } \\
\hline$L$ & 2.14 & .73 & 2.6 & 19 \\
\hline $\mathrm{M}$ & 2.26 & .64 & 6.4 & 34 \\
\hline $\mathrm{H}$ & 2.91 & .86 & 6.9 & 29 \\
\hline \multicolumn{5}{|l|}{ Claude } \\
\hline L & 2.59 & .88 & 3.7 & 19 \\
\hline $\mathrm{M}$ & 2.02 & 84 & 2.4 & 11 \\
\hline $\mathrm{H}$ & 2.56 & .82 & 4.7 & 23 \\
\hline \multicolumn{5}{|l|}{ Lockhart } \\
\hline L & 2.75 & .88 & 4.7 & 23 \\
\hline M & 2.57 & .85 & 5.6 & 21 \\
\hline $\mathrm{H}$ & 2.02 & .84 & 2.9 & 11 \\
\hline Seagrass & 2.39 & .60 & 8.3 & 53 \\
\hline \multicolumn{5}{|l|}{ Escape } \\
\hline L & 2.91 & .81 & 6.2 & 37 \\
\hline M & 2.58 & .91 & 3.8 & 17 \\
\hline $\mathrm{H}$ & 2.43 & .83 & 4.5 & 19 \\
\hline \multicolumn{5}{|c|}{ Hinchinbrook } \\
\hline L & 2.18 & .83 & 2.4 & 14 \\
\hline M & 2.48 & .92 & 3.2 & 15 \\
\hline $\mathrm{H}$ & 2.07 & .76 & 4.2 & 15 \\
\hline
\end{tabular}

Species diversity, evenness and species richness ranged from 2.02 to $2.91,0.60$ to 0.92 and 2.4 to 8.3 , respectively; number of species ranged from 11 to 53 species per site (Table 3). Diversity, evenness and species richness were neither significantly different $(p>0.05)$ among estuaries, nor were consistent patterns evident among intertidal zones. Diversity correlated only with species richness $(r=+0.54)$, whereas evenness and species richness correlated with redox potential ( $\mathrm{r}=+0.61)$ and percent sand $(\mathrm{r}=+0.54)$, respectively. Diversity was highest in the high and low intertidal zones of the Morgan/McIvor and Escape Rivers, and lowest in the mid and high intertidal zones of the Claude and Lockhart Rivers, respectively. The greatest number of species (53) occurred in the Lockhart River seagrass bed.

\section{Inter-estuary variation and intertidal zonation}

\section{Classification and ordination of stations}

The normal classification of the Hinchinbrook Island fauna (all seasons and species identified) revealed that the low and high intertidal zones classified separately (Fig. 3 top), but that the mid intertidal collections often classified with the other 2 zones. The ordination of the collections demonstrates a clearer distinction among the 3 intertidal zones (Fig. 3 bottom). Although a few sites are closer to those in other zones along the first 2 axes, as indicated by the dotted lines, there was no overlap among the 3 intertidal zones.

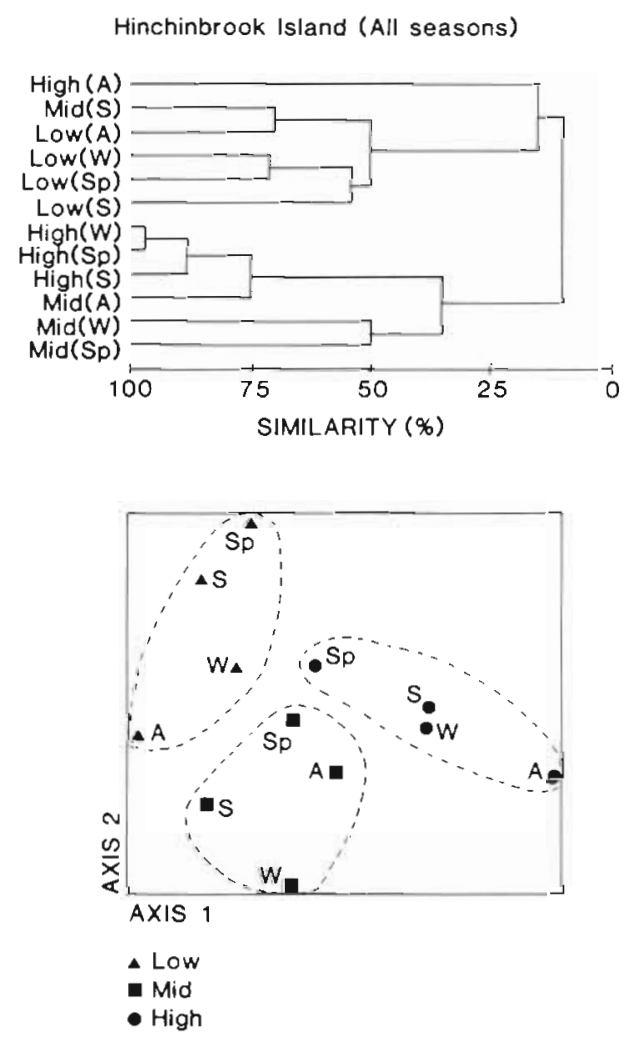

Fig. 3. Top: Normal classification of mangrove sites at Missionary Bay, Hinchinbrook Island, using all nematode species identified (all seasons). Bottom: Detrended correspondence analysis of collections of nematodes from stations at Missionary Bay, Hinchinbrook Island. A: autumn; Sp: spring; S: summer; $W$ - winter

Because a wide range of Bray-Curtis similarity values were calculated between summer and winter collections of nematodes from the Cape York estuaries (35 to $90 \%$ ) with no consistent trends, numerical classification of the Cape York stations was performed combining summer and winter collections and using all 205 species identified. The normal classification of the Cape York sites revealed low to moderate similarity 

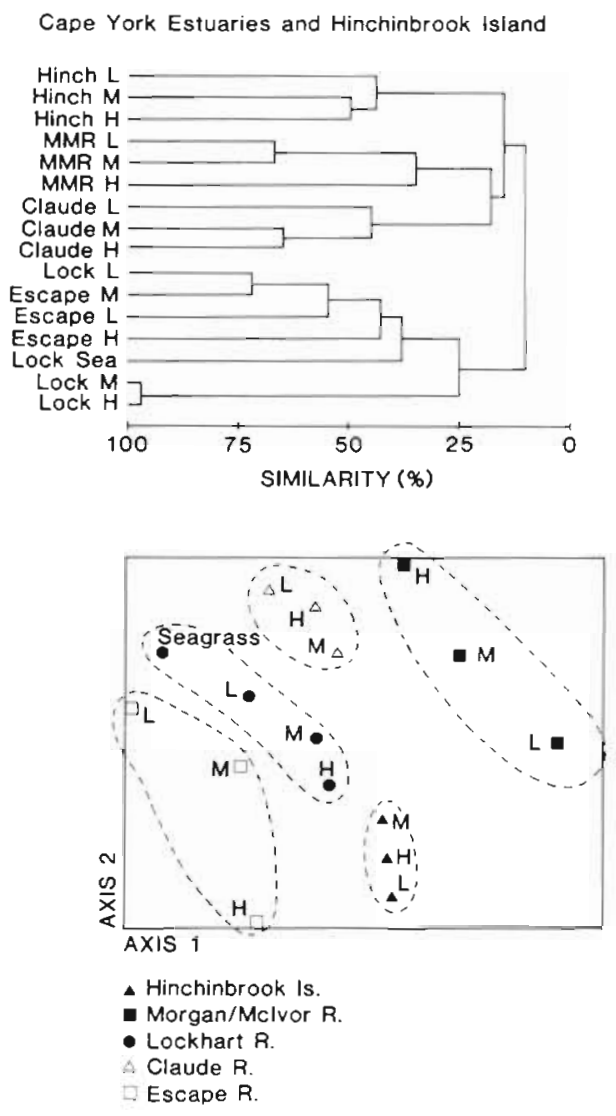

Fig. 4. Top: Normal classification of stations in the 5 mangrove estuaries along the Cape York peninsula using all species identified (winter and summer). Bottom: Detrended correspondence analysis of collections of nematodes from sites along the Cape York peninsula (5 mangrove estuaries). L: low intertidal; $\mathrm{M}$ : mid intertidal; $\mathrm{H}$ : high intertidal

$(<50 \%$ ) among the Hinchinbrook, Claude and Morgan/McIvor estuaries, but that the Lockhart and Escape River Stations often classified together (Fig. 4 top). The distinction among estuaries is more clearly demonstrated in the spatial model constructed by DCA (Fig. 4 bottom). In the DCA, the first 2 axes explain a large proportion of the variance (eigenvalues of 0.780 and 0.594 , respectively). Axis 1 divides the southern estuaries (Hinchinbrook Island and Morgan/McIvor systems) with moderate to high sets of scores from the northern estuaries (Claude, Lockhart and Escape Rivers) with low to moderate sets of scores along the axis. The trend separating the estuaries along Axis 2 is not clear, but the intertidal sites within each estuary are more clearly separated as ellipses along this axis than on the first axis.

\section{Species associations}

Using the criteria detailed earlier (see data analysis), 10 species groups were formed from the inverse classification (Table 4) and were further analyzed using nodal analysis. The patterns of constancy and fidelity of the species groups (Fig. 5) suggest that the fair separation among intertidal zones and estuaries is a result of species assemblages that are moderately to highly faithful (fidelity) to a particular estuary and zone. Species Group 1 occurred primarily on Hinchinbrook Island and in the Morgan/McIvor system. Species Group 2 consists of species primarily inhabiting the freshwater-influenced Claude River. Species of Groups 3 and 6 also occurred mainly at Hinchinbrook Island. Minor species comprising Group 8 displayed a strong preference for the Morgan/Mclvor and Claude systems, whereas species Groups 4 and 7 occurred in all 5 estuaries. Species in Group 4, Terschellingia longicaudata, Trissonchulus oceanus and Anoplostoma viviparum, were among the most abundant of the 205 species identified and occurred consistently (high constancy) in each estuary, but were more abundant in and faithful to sites in the Lockhart and Escape Rivers, particularly the most abundant species, $T$. longicaudata. Species classified in Groups 5, 9 and 10 occurred primarily in the Lockhart and Escape Rivers; in particular, species of Group 10 occurred almost exclusively in the seagrass bed of the Lockhart River.

\section{Distribution of trophic types}

With the exception of 3 stations, deposit-feeders were the dominant feeding type among intertidal zones and estuaries (Fig. 6). In the low intertidal zones of Missionary Bay and the Escape River, epigrowth-feeders were the most abundant trophic group, whereas omnivore/predators were the dominant trophic group in the mid intertidal zone of the Claude estuary. Combining all sites, deposit-feeders were the dominant group $(\overline{\mathrm{x}}=50 \%)$ with epigrowth-feeders and omnivore/predators averaging 28 and $22 \%$ of the total nematode fauna.

\section{DISCUSSION}

The classification and ordination models in concert with the nodal analysis indicated that nematode community composition generally differed among the 3 intertidal zones and among mangrove estuaries in the northeastern Australian tropics. Previous studies in this region have suggested that physical and chemical factors such as temperature, sediment granulometry and soluble tannins leached from various components of mangrove trees play important roles in determining the zonation patterns and seasonal changes of microbenthos and meiofauna (Alongi 1987a, b, c). It is not 
Table 4. Mean relative abundances of nematodes agglomerated into groups following inverse classification. Values represent abundances of each species averaged for the 3 different intertidal zones of each estuary. Only species with mean relative abundances $>1.0 \%$ in at least one of the 5 systems are listed individually. Minor species are grouped within each agglomeration.

$$
-=\text { absent }
$$

\begin{tabular}{|c|c|c|c|c|c|}
\hline Species & Hinchinbrook & Morgan/Mclvor & Claude & Lockhart & Escape \\
\hline \multicolumn{6}{|l|}{ Species Group 1} \\
\hline Spirinia parasitifera & 3.5 & 2.7 & - & 2.4 & - \\
\hline Oxystomina sp. 1 & 1.2 & 1.2 & - & - & - \\
\hline Terschellingia sp. 1 & 0.2 & 4.0 & - & 0.9 & - \\
\hline Neochromadora sp. 1 & - & 12.3 & - & - & - \\
\hline Sabatieria punctata & - & 8.5 & - & - & - \\
\hline Metalinhomoeus setosus & - & 33.1 & - & - & - \\
\hline Parodontophora brevamphida & - & 2.9 & - & - & - \\
\hline Paramonhystera sp. 1 & - & 3.2 & - & - & - \\
\hline Halalaimus sp. 1 & - & 1.9 & - & - & - \\
\hline Steineria sp. 1 & - & 1.3 & - & - & - \\
\hline Adoncholaimus sp. 1 & - & 1.5 & - & - & - \\
\hline Others $^{d}$ & 1.0 & 1.0 & - & - & - \\
\hline \multicolumn{6}{|c|}{${ }^{a}$ Theristus sp. 1, Microlaimus sp. 1, Chromadorella sp. 1, Paraspherolaimus sp. 1, Oncholaimus sp. 1, Viscosia sp. 2} \\
\hline \multicolumn{6}{|l|}{ Species Group 2} \\
\hline Spilophorella sp. 1 & - & 0.5 & 4.1 & - & - \\
\hline Sabatieria granifer & - & - & 7.8 & - & - \\
\hline Oncholaimus oxyuris & - & - & 2.7 & - & - \\
\hline Siphonolaimus sp. 1 & - & - & 1.4 & - & - \\
\hline Calyptonema sp. 2 & - & - & 1.0 & - & - \\
\hline Hopperia sp. 2 & - & - & 1.0 & - & - \\
\hline Others $^{d}$ & - & - & 1.4 & - & - \\
\hline \multicolumn{6}{|c|}{ 'Monoposthia sp. 1, Adorus tenuis, Parodontophora cephalata, Theristus sp. 2} \\
\hline \multicolumn{6}{|l|}{ Species Group 3} \\
\hline Chromadora sp. 1 & 2.3 & - & - & - & - \\
\hline Pseudochromadora cephalata & 2.6 & - & - & - & - \\
\hline Microlaimus sp. 2 & - & 2.0 & - & - & - \\
\hline Haliplectus sp. 1 & 1.4 & - & - & - & - \\
\hline Araeolaimus sp. 1 & 1.9 & - & - & - & - \\
\hline Phandoderma ocellatum & 1.4 & - & - & - & 0.5 \\
\hline \multicolumn{6}{|l|}{ Prochromadorella } \\
\hline paramucrodonta & 3.5 & - & - & - & 2.3 \\
\hline Paracyatholaimus sp. 1 & 5.8 & - & - & - & - \\
\hline Paradesmodora campbelli & 3.0 & - & - & - & - \\
\hline Paracomesoma dubium & 21.0 & - & - & - & - \\
\hline Diplolaimella sp. 1 & 10.0 & 0.2 & - & - & - \\
\hline Sphaerolaimus lodosus & 3.3 & - & 2.4 & - & - \\
\hline Sphaerolaimus cuneatus & 2.1 & - & - & - & - \\
\hline Theristus sp. 4 & 1.2 & - & - & - & - \\
\hline Others ${ }^{\circ}$ & 2.8 & - & 0.7 & - & - \\
\hline \multicolumn{6}{|c|}{$\begin{array}{l}\text { "Laimella longicaudata, Theristus sp. 3, Viscosia sp. 1, Axonolaimus sp. 1, Parodontophora sp. 1, Phandoderma cocksi, } \\
\text { Paradesmodora sp. 1, Monoposthia sp. 2, Microlaimus problematicus }\end{array}$} \\
\hline \multicolumn{6}{|l|}{ Species Group 4} \\
\hline Terschellingia longicaudata & 17.8 & 11.5 & 2.4 & 38.6 & 16.3 \\
\hline Trissonchulus oceanus & 1.2 & 0.7 & 14.2 & 0.8 & 1.6 \\
\hline Anoplostoma viviparum & 1.4 & 2.7 & 12.5 & 0.9 & 1.1 \\
\hline \multicolumn{6}{|l|}{ Species Group 5} \\
\hline Paramonhystera biforma & - & - & - & 2.4 & 0.9 \\
\hline Theristus sp. 5 & - & 1.2 & - & - & - \\
\hline Sphaeolaimus sp. 1 & - & - & - & 1.1 & 3.8 \\
\hline Dorylaimus punctata & - & - & - & 1.7 & 10.6 \\
\hline Viscosia viscosia & - & - & - & 13.0 & 2.5 \\
\hline Araeolaimus sp. 2 & - & - & - & 1.4 & - \\
\hline Sphaeolaimus maeoticus & - & - & - & 1.0 & - \\
\hline
\end{tabular}


Table 4 (continued)

\begin{tabular}{|c|c|c|c|c|c|}
\hline Species & Hinchinbrook & Morgan/McIvor & Claude & Lockhart & Escape \\
\hline \multicolumn{6}{|l|}{ Species Group 5 (continued) } \\
\hline Microlaimus sp. 4 & - & - & - & 1.6 & - \\
\hline Sphaeolaimus sp. 2 & - & - & - & - & 1.4 \\
\hline Paradesmodora sp. 2 & - & - & 1.0 & - & - \\
\hline Metalinhomoeus sp. 1 & - & - & 1.7 & - & - \\
\hline Others $^{a}$ & - & 0.1 & 0.2 & 8.2 & 7.9 \\
\hline \multicolumn{6}{|c|}{ 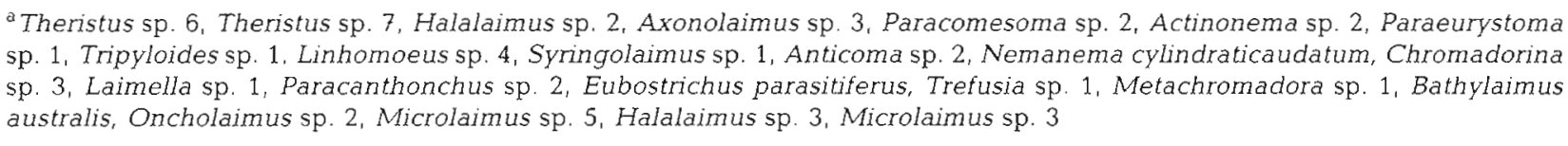 } \\
\hline \multicolumn{6}{|l|}{ Species Group 6} \\
\hline Didelta cobbj & 1.9 & - & - & - & - \\
\hline Anticoma sp. 1 & 1.2 & - & - & - & - \\
\hline Theristus quadripapillus & 2.1 & - & - & - & - \\
\hline Monhystera filicaudata & 1.4 & - & - & - & - \\
\hline Chromadora sp. 3 & 1.2 & - & - & - & - \\
\hline Others $^{a}$ & 2.4 & - & - & - & - \\
\hline \multicolumn{6}{|c|}{${ }^{2}$ Spirinia sp. 1, Chromadora sp. 2, Euchromadora sp. 1, Quadricoma sp. 1} \\
\hline \multicolumn{6}{|l|}{ Species Group 7} \\
\hline \multicolumn{6}{|l|}{ Halicholaimus } \\
\hline quattuordecimpapillata & 1.2 & - & 4.7 & 0.6 & 1.6 \\
\hline Desmodora cephalata & - & - & 5.1 & 0.9 & 0.2 \\
\hline Crenopharynx sp. 1 & - & - & 1.7 & 0.5 & - \\
\hline Sabatieria wieseri & - & - & 7.4 & 1.2 & 1.8 \\
\hline Metachromadora clavata & - & 0.3 & 1.4 & 0.2 & 0.2 \\
\hline Thalassoalaimus setosus & - & - & 4.0 & 0.1 & - \\
\hline Adoncholaimus fuscus & - & - & 3.7 & - & 0.4 \\
\hline Metoncholaimus sp. 1 & - & - & 2.7 & - & - \\
\hline Anoplostoma sp. 1 & - & 0.1 & 2.0 & - & - \\
\hline Acanthopharynx distechei & - & - & 5.1 & - & - \\
\hline Others $^{\mathrm{A}}$ & - & 0.5 & 2.2 & 0.2 & 0.6 \\
\hline \multicolumn{6}{|c|}{$\begin{array}{l}\text { axystomina sp. 2, Subsphaerolaimus sp. 1, Desmodora sp. 3, Haliplectus sp. 2, Chromadorina sp. 2, Viscosia sp. 3, Synonchus } \\
\text { sp. 1, Axonolaimus sp. } 2\end{array}$} \\
\hline \multicolumn{6}{|l|}{ Species Group 8} \\
\hline Others ${ }^{a}$ & - & 6.5 & 4.5 & 0.1 & - \\
\hline \multicolumn{6}{|c|}{ 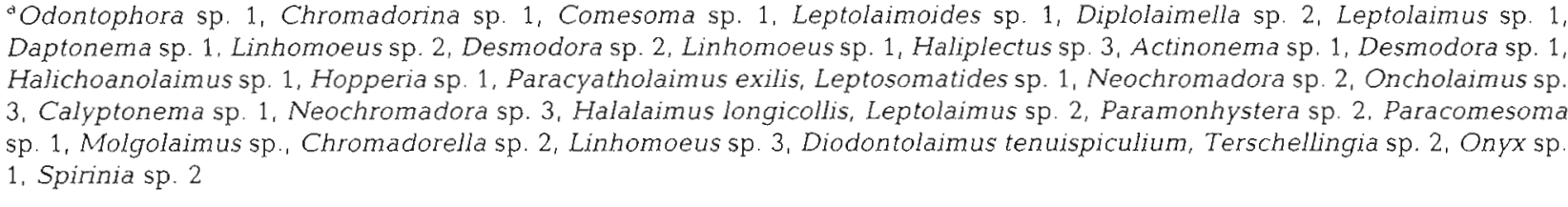 } \\
\hline \multicolumn{6}{|l|}{ Species Group 9} \\
\hline Dichromadora apapillata & - & - & - & 0.4 & 7.9 \\
\hline Theristus sp. 8 & - & - & - & 1.2 & 2.5 \\
\hline Comesoma sp. 2 & - & - & - & 0.2 & 4.7 \\
\hline Cheironchus vorax & - & - & - & 0.4 & 3.4 \\
\hline Acanthonchus sp. 1 & - & - & - & - & 12.0 \\
\hline Longicyatholaimus maldivarium & - & - & - & - & 2.9 \\
\hline Paracanthonchus sp. 1 & - & - & - & - & 2.9 \\
\hline Paramonhystera megacephala & - & - & - & - & 1.8 \\
\hline Paramonhystera proteus & - & - & - & - & 1.1 \\
\hline Others $^{\mathrm{a}}$ & - & - & - & - & 6.9 \\
\hline
\end{tabular}


Table 4 (continued)

\begin{tabular}{|c|c|c|c|c|c|}
\hline Species & Hinchinbrook & Morgan/McIvor & Claude & Lockhart & Escape \\
\hline \multicolumn{6}{|l|}{ Species Group 10} \\
\hline \multicolumn{6}{|l|}{ Parodontophora } \\
\hline paragranulifera & - & - & 1.0 & 1.4 & - \\
\hline Metacyatholaimus sp. 1 & - & - & - & 2.5 & - \\
\hline Spirinia laevoides & - & - & - & 2.0 & - \\
\hline Metalinhomoeus filiformis & - & - & - & 1.3 & - \\
\hline Paradesmodora sp. 3 & - & - & - & 1.3 & - \\
\hline Oxystomina elongata & - & - & - & 1.5 & - \\
\hline Theristus acribus & - & - & - & 1.4 & - \\
\hline Others ${ }^{\bar{a}}$ & - & 0.1 & - & 8.6 & 0.2 \\
\hline
\end{tabular}

CONSTANCY

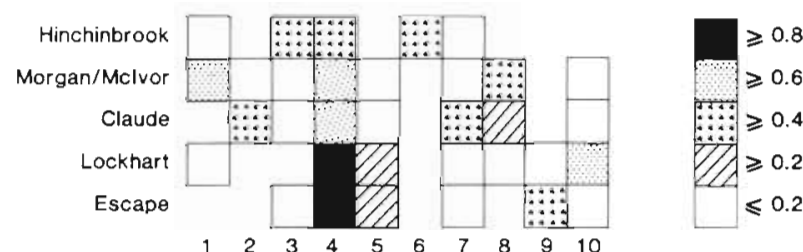

FIDELITY

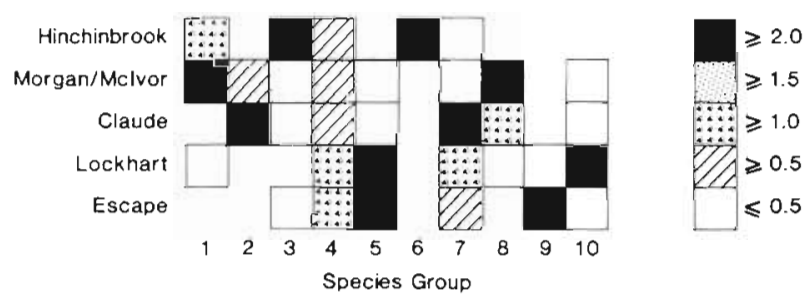

Fig. 5. Nodal analysis showing constancy and fidelity indices of nematode species groups in each mangrove estuary. See Table 4 for species comprising each group

unreasonable to assume that these factors and others not examined (e.g. disturbance, predation, etc.) also regulate community structure of nematodes in these same estuaries.

\section{Inter-estuary variation}

Differences in physical characteristics, mangrove forest productivity and food availability can be cited as possible determinants influencing the development of different nematode communities among estuaries. Because information on variation of nematode com-

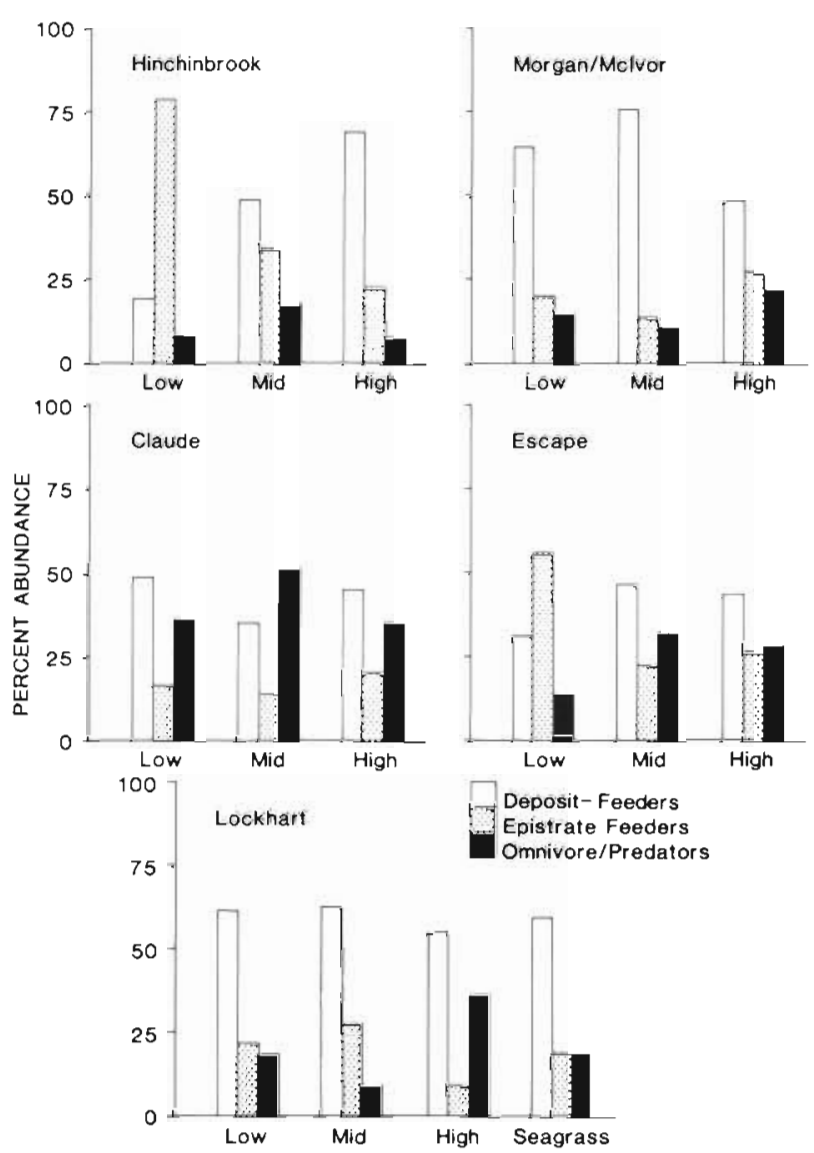

Fig. 6. Trophic structure of nematode assemblages (percentage of relative abundance) in the mangrove estuaries (all stations)

munity structure among estuaries is lacking, it is difficult to speculate on the processes fostering differences among communities. Undoubtedly, however, 
physical factors such as salinity will assist in determining community composition and structure. For example, the generally lower salinities in the Morgan/ McIvor, Claude and Escape Rivers compared to the other 2 systems would lead to the establishment of faunal groups that prefer estuarine conditions. Indeed, most of the nematodes comprising Species Groups 1, 2, 7,8 and 9 were found primarily in the Morgan/Mclvor, Claude and Escape River systems, which are greatly influenced by freshwater runoff.

A reasonable hypothesis to explain inter-estuary differences is that all nematode species have an equal probability of colonizing a particular estuary, but that factors peculiar to each estuary foster the establishment of a fairly distinct assemblage over time. Competition and predation in concert with biological disturbance (e.g. bioturbation) and within-estuary dispersal patterns, probably also play crucial roles in determining community composition.

\section{Intertidal zonation}

In addition to low similarity of nematode assemblages among estuaries, intertidal zonation both in densities and community structure of nematodes prevailed in each estuary. The few studies that have investigated intertidal zonation of nematodes similarly found fairly distinct patterns across the intertidal (e.g. Ott 1972, Platt 1977) and attributed species patterns to gradients in physicochemical factors such as sediment grain size, temperature and microbial food resources. In the same estuaries examined in this study, Alongi $(1987 \mathrm{a}, \mathrm{b})$ found that soluble tannins and traditionallyconsidered physical factors (e.g. temperature) rather than variations in the quantity and quality of microbial food correlated significantly with meiofaunal densities. It is probable that differences in these physical and chemical factors across the intertidal similarly influence species zonation of nematodes.

The zonation patterns of nematodes within an estuary may also be dependent upon differences in colonizing ability. Dispersal ability varies widely among nematode species (Eskin \& Palmer 1985) and may be a function of hydrodynamics and above-ground (e.g. plant shoots, prop roots) structure (Palmer 1986). It is conceivable that nematode colonization of the different intertidal zones in mangrove estuaries is inhibited by the trapping of tidal waters and freshwater runoff within the forest in the wet season. Wolanski \& Ridd (1986) recently concluded that lateral transport of water (both tidal and freshwater runoff) between intertidal zones lags behind prevailing tidal cycles in these estuaries. The residence time of water in mangrove forests can be quite long.

\section{Comparisons with other intertidal habitats}

Alongi (1987a, b, c) concluded that tropical intertidal benthos in these estuaries are subjected to greater physical stress than temperate intertidal communities. Such stress may be reflected in the relatively low species diversity (2.05 to 2.91) and number of species (11 to 53) inhabiting the mangroves. Low species diversity of nematodes has been abserved in other tropical habitats, particularly in other regions of the IndoPacific (Gerlach 1962, Boucher 1973, Decreamer \& Coomans 1978a, b, Alongi 1986). Low rates of organic matter deposition, rapid rates of detrital utilization and high disturbance rates by large infauna have been cited as factors leading to low nematode diversity in the tropics (Alongi 1986).

Species diversity and/or species richness of intertidal nematode communities from exposed to sheltered beaches along the North American and European coasts (Ott 1972, Platt 1977, Heip et al. 1985) and in other mangrove habitats (Hopper et al. 1973, Fell et al. 1975, Krishnamurthy et al, 1984, Hodda \& Nicholas 1985, 1986a, b) are generally higher than the values reported here. Ott (1972) examined species diversity of nematodes from an intertidal sandflat in North Carolina and found that diversity increased from the high to the low interticlal. In this study, however, there were no consistent trends in species diversity, richness and evenness across the intertidal zones among estuaries.

The distribution and abundance of nematode feeding types in this study were not greatly different from other intertidal nematode communities, but abundances of predatory species do appear to be greater in the tropics (Krishnamurthy et al. 1984, Alongi 1986, this study). On a coral reef, Alongi (1986) observed a relatively high (20 to $48 \%$ ) percentage of predatory species which was attributed to the oligotrophic nature of reefal systems as well as to higher rates of predation usually ascribed to the tropics.

Previous mangrove investigations (Hopper et al. 1973, Fell et al. 1975, Krishnamurthy et al. 1984) also found unusual dominance of predatory genera such as Sphaerolaimus, Enoplus and Viscosia, particularly on decaying wood, roots and leaves. Whereas Krishnamurthy et al. (1984) maintained that nematodes on leaf litter, wood and roots constitute a distinct community compared to the sediment dwelling fauna, Fell et al. (1975) could not identify a specific litter assemblage. During this study, very few nematodes on decaying mangrove leaves (usually $<5$ leaf $^{-1}$ ) and wood litter (own obs.) were found. All of the leaf-dwelling nematodes were predatory species suggesting that they may be less sensitive to soluble tannins leached from this litter than deposit-feeders (Alongi 1987b). In 
any event, on the basis of numbers, the litter-dwelling fauna in Australian mangroves constituted an insignificant ( $<3 \%$ of total sediment densities) assemblage compared to the sediment fauna and was not examined further.

In conjunction with the other studies of mangrove nematode communities (Gerlach 1956a, b, 1957. Decreamer \& Coomans 1978a, b, Krishnamurthy et al. 1984), it is evident that there are apparently few numerically-dominant species endemic to mangroves. The 5 dominant species found in this study - Terschellingia longicaudata, Metalinhomoeus setosus, Anoplostoma viviparum, Paracomesoma dubium, and Trissonchulus oceanus - are cosmopolitans capable of surviving large fluctuations in environmental conditions (Heip et al. 1985). The 5 mangrove estuaries along the northeastern Australian coast possess fairly different nematode communities, but nearly all of the dominant nematodes identified to species level are common inhabitants of intertidal sediments in other world oceans.

Acknowledgements. This study was supported by Marine Sciences and Technologies Grant No. 86/0708 to the author and by the Australian Institute of Marine Science. Norm Duke helped with the computer analyses, my wife Fiona drafted the figures, and A. Robertson reviewed the manuscript. Masters and crews of RV 'Harry Messel' and RV 'Lady Basten' are thanked for assistance on both cruise legs.

\section{LITERATURE CITED}

Alongi, D. M. (1986). Population structure and trophic composition of the free-living nematodes inhabiting carbonate sands of Davies Reef, Great Barrier Reef. Aust. J. mar Freshwat. Res. 37: 609-619

Alongi, D. M. (1987a). Intertidal zonation and seasonality of meiobenthos in tropical mangrove estuaries. Mar. Biol. 95: in press

Alongi, D. M. (1987b). The influence of mangrove-derived tannins on intertidal meiobenthos in tropical estuaries. Oecologia (Berl.) 71: 537-540

Alongi, D. M. (1987c). Bacterial productivity and microbial biomass in tropical mangrove sediments. Microb. Ecol. 14: in press

Boesch, D. F. (1977). Application of numerical classification in ecological investigations of water pollution. U.S. Environmental Protection Agency, Ecological Research Series, EPA-600/3-77-033

Boto, K. G., Wellington, J. T. (1984). Soil characteristics and nutrient status in a Northern Australian mangrove forest. Estuaries 7: 61-69

Boucher, G. (1973). Nematodes litres marine des ils hautes de Polynesia. I. Comesomatidae et Axonolaimidae. Cah. Pac. 17: 205-230

Bray, J. R., Curtis, J. T. (1957). An ordination of upland forest communities of southern Wisconsin. Ecol. Monogr. 27: 325-349

Bunt, J. S. (1982). Studies of mangrove litter fall in tropical Australia. In: Clough, B. F. (ed.) Mangrove ecosystems in
Australia. Australian National Univ. Press, Canberra, p. $223-237$

Bunt, J. S., Williams, W. T., Clay, H. J. (1982a). River water salinity and the distribution of mangrove species along several rivers in North Queensland. Aust. J. Bot. 30: $401-412$

Bunt, J. S., Williams, W. T., Duke, N. C. (1982b). Mangrove distributions in north-east Australia. J. Biogeogr. 9: $111-120$

Clifford, H. T., Stephenson, W (1975). An introduction to numerical classification. Academic Press, New York

Decreamer, W., Coomans, A. (1978a). Scientific report on the Belgian expedition to the Great Barrier Reef in 1967. Nematodes. XII. Ecological notes on the nematode fauna in and around mangroves on Lizard Island. Aust. J. mar. Freshwat. Res. 29: 497-508

Decreamer, W., Coomans, A. (1978b). Scientific report on the Belgian expedition to the Great Barrier Reef in 1967. Nematodes. XIII. A description of four known species from in and around mangroves on Lizard Island. Aust. J. mar. Freshwat. Res. 29: 509-541

Eskin, R. A., Palmer, M. A. (1985). Suspension of marine nematodes in a turbulent tidal creek: species patterns. Biol. Bull. mar. biol. Lab., Woods Hole 169; 615-623

Fell, J. W., Cefalu, R. C., Master, I. M., Tallman, A. S. (1975). Microbial activities in the mangrove (Rhizophora mangle) leaf detrital system. In: Walsh, G., Snedaker, S., Teas, H. (ed.) Proceedings International Symposium Biol. Manag. Mangroves. Univ. of Florida Press, Gainesville, p. 661-679

Galloway, R. W. (1982). Distribution and physiographic patterns of Australian mangroves. In: Clough, B. F. (ed.) Mangrove ecosystems in Australia. Australian National Univ. Press, Canberra, p. 31-54

Gerlach, S. A. (1956a). Brasilianische Meeres-Nematoden. I. Boln. Inst. esp. Oceanogr. 5: 3-69

Gerlach, S. A. (1956b). Die Nematodenbesiedlung des tropischen Brandungsstrandes von Pernambuco. Brasilianische Meeres-Nematoden. II. Kieler Meeresforsch. (Sonderh.) 12: $202-218$

Gerlach, S. A. (1957). Marine Nematoden aus dem Mangroven-Gebiet von Cananeia (Brasilianische MeeresNematoden III). Abh. Math.-Naturw. Kl. Akad. Wiss. Mainz 5: 129-176

Gerlach, S. A. (1962). Freilebende Meeresnematoden von den Malediven. Kieler Meeresforsch. (Sonderh.) 18: 81-108

Heip, C., Vincx, M. Vranken, G. (1985). The ecology of marine nematodes. Oceanogr. mar. Biol. A. Rev. 23: 399-489

Hill, M. O. (1979). DECORANA a FORTRAN program for detrended correspondence analysis and reciprocal averaging. Ecology and Systematics, Cornell Univ. Press, Ithaca

Hill, M. O., Gauch, H. G. (1980). Detrended correspondence analysis: an improved ordination technique. Vegetatio 43 : $377-389$

Hodda, M., Nicholas, W. L. (1985). Meiofauna associated with mangroves in the Hunter River estuary and Fullerton Cove, southeastern Australia. Aust. J. mar. Freshwat. Res. 36: $41-50$

Hodda, M., Nicholas, W. L. (1986a). Temporal changes in littoral meiofauna from the Hunter River estuary. Aust. J. mar. Freshwat. Res. 37: 729-741

Hodda, M., Nicholas, W. L. (1986b). Nematode diversity and industrial pollution in the Hunter River Estuary, NSW, Australia. Mar. Pollut. Bull. 17: 251-255

Hopper, B. E., Fell, J. W., Cefalu, R. C. (1973). Effect of temperature on life cycles of nematodes associated with the mangrove (Rhizophora mangle) detrital system. Mar Biol. 23: 293-296 
Krishnamurthy, K., Sultan Ali, M. A., Jeyseelan, M. J. P. (1984) Structure and dynamics of the aquatic food web community with special reference to nematodes in mangrove ecosystems. Proc. As. Symp. Mangr. Env. Res. Mang. 1. 429-452

Lambert, J. M., Williams, W. T. (1962). Multivariate methods in plant ecology. IV. Nodal analysis. J. Ecol, 50: 775-802

Macnae, W. (1969). A general account of the fauna and flora of mangrove swamps and forests in the Indo-West Pacific region. Adv. mar. Biol. 6: 73-270

Margalef, R. (1958). Information theory in ecology. Gen. Syst. 3 $36-71$

Milward, N. E. (1982). Mangrove-dependent biota. In: Clough, B. F. (ed.) Mangrove ecosystems in Australia. Australian National Univ. Press, Canberra, p. 121-139

Moriarty, D. J. W., Pollard, P. C., Alongi, D. M., Wilkinson, C. R., Gray, J. S. (1985). Bacterial productivity and trophic relationships with consumers on a coral reef. Proc. 5th Int. Coral Reef Congr. 5: $457-462$

Ott, J. A. (1972). Determination of faunal boundaries of nematodes in an intertidal sandflat. Int. Revue ges. Hydrobiol. 57: 645-663
Palmer, M. A. (1986). Hydrodynamics and structure: interactive effects on meiofauna dispersal. J. exp. mar. Biol. Ecol. 104: $53-68$

Pielou, E. C. (1975). Ecological diversity. Wiley, New York

Pielou, E. C. (1984). The interpretation of ecological data. Wiley, New York

Platt, H. M. (1977). Ecology of free-living marine nematodes from an intertidal sandflat in Strangford Lough, Northem Ireland. Estuar. coast. Shelf Sci. 5: 685-693

Sokal, R. R., Rohlf, R. J. (1969). Biometry. Freeman, San Francisco

Tietjen, J. H. (1984). Distribution and species diversity of deep-sea nematodes in the Venezuela Basin. Deep Sea Res. 31: 119-132

Wieser, W. (1953). Die Beziehung zwischen Mundhöhlengestalt, Ernährungsweise und Vorkommen bei freilebenden marinen Nematoden. Ark. Zool. 4: 439-484

Wolanski, E., Ridd, P. (1986). Tidal mixing and trapping in mangrove swamps. Estuar. coast. Shelf Sci. 23: 759-771

This article was submitted to the editor; it was accepted for printing on July 15, 1987 